\title{
QFD method application in the process of hotel service quality improvement
}

\author{
Sandra Milunović Koprivica ${ }^{*}$, Cariša Bešić ${ }^{1}$, Olga Ristić ${ }^{1}$ \\ ${ }^{1}$ University of Kragujevac, Faculty of Technical Sciences in Čačak, Serbia
}

\begin{abstract}
QFD method has been applied mainly in industrial companies. The service is intangible product that has its own specificities, and the market of hotel services in our country is becoming saturated. The aim of this paper is the identification of the most important quality characteristics (technical characteristics) of the hotel service and the direction of the hotel management activities to those characteristics that can be related to the highest number of stated customer requirements. Therefore, the result of the research is to define the key characteristics of the service quality and key activities in the design of the service that lead to customer satisfaction and achieving a competitive advantage in the market. Considering the results of the previous QFD method research, especially in the domain of this type of services, and especially in our country, one might say that even a small contribution to this matter is visible and could give impetus, not only for further research in this field, but also for the concrete application of the obtained solutions.
\end{abstract}

Keywords: hotel service, quality, improvement, QFD method JEL classification: L15, L83

\section{Primena QFD metode u procesu unapređenja kvaliteta hotelske usluge}

Sažetak: QFD metoda se do sada primenjivala pre svega u industrijskim preduzećima. Usluga je nematerijalni proizvod koji ima svoje specifičnosti, a tržište hotelskih usluga kod nas postaje sve zasićenije. Cilj ovog rada je identifikacija najznačajnijih karakteristika kvaliteta (tehničkih karakteristika) hotelske usluge i usmeravanje aktivnosti menadžmenta hotela na one karakteristike koje se mogu dovesti u vezu sa najvećim brojem iskazanih korisničkih zahteva. Dakle, rezultat istraživanja je definisanje ključnih karakteristika kvaliteta usluge i ključnih aktivnosti u projektovanju usluge koje dovode do zadovoljstva korisnika i ostvarenja konkurentske prednosti na tržištu. S obzirom na rezultate dosadašnjih istraživanja QFD metode u domenu ove vrste usluga u našoj zemlji, moglo bi se reći da je čak i mali doprinos toj materiji vidljiv i mogao bi dati podsticaj, ne samo za dalja istraživanja u ovoj oblasti, već i za konkretnu primenu dobijenih rešenja.

Ključne reči: hotelska usluga, kvalitet, unapređenje, QFD metoda JEL klasifikacija: L15, L83

\footnotetext{
* sandra.milunovic@ftn.kg.ac.rs

** This paper presents the part of research conducted under the project III 46001- Creating wealth from the wealth of Serbia, funded by Ministry of education, science and technological development of the Republic of Serbia (2011-2019).
} 


\section{Introduction}

The market principle in the business and implementation of the management concept become universal requirements without which one can hardly imagine survival in the tourist-hotel business. Tourism, among other things, is distinguished by a very specific manifestation of the demands of users arising during travel and stay outside the place of residence. The starting point is that the needs, desires and expectations of hotel guests go beyond the existential sphere and should not be reduced only to a comfortable room, a clean and comfortable bed, or a simple and plentiful meal. If the average annual utilization of the hotel capacities is low, its key problem is the small number of guests. The possible cause is noncompliance with the requirements of the users (guests). The way to find solution to this problem is to determine the users' requirements, that is, their needs, wishes and expectations that the hotel can realistically fulfil, with its material, technical, organizational and human resources (Redžić, 2018).

In order to achieve sufficient quality of service, it is necessary to present clearly agreed and harmonized requirements along with the customer requirements. Discovering the needs and wishes of customers is essential, but those requirements and needs need to be translated into technical business language. As a result, a company should focus on errors in existing services and attempt to eliminate them or try to assess what customers really want (Boucherau \& Rowlands, 2000). Quality Function Deployment (QFD) is used as an important part of the process of developing a new service. After the introduction of the QFD method, a theoretical framework for a three-phase action plan based QFD flowdown process in the hotel industry is given in this paper.

The volume and complexity of the service and its representation in the total economy in the world of 55\%, compared to the industries and agriculture that participate with $45 \%$, gives this category strategic importance. Assumptions are that services in 30 years will be represented in the global economy with around $30 \%$.

The quality of services is defined differently depending on which aspect it is viewed. For a service provider, the notion of quality can have a rounded definition, which it does not have to, and very often does not match the view of the user. First of all, it is important to know that there is not only one type of service user, but that number is far higher, with each having different requirements and expectations from the service provided. Another important element in defining the concept of quality of service is the constant knowledge, experience and familiarization with new services, which also leads to new expectations from users. Service is very often a combination of material, intangible elements and interpersonal relationships. In shaping the quality of service, as a rule, the physical aspect is always emphasized, while the latter, no less important, is in the background. For example, in every tourist offer, the size of the hotel, room, reception and the like are emphasized, and to a lesser extent the atmosphere, comfort, brightness, warmth, courtesy and the like. The issue of service quality is very complex and demanding, as its specifics point to. More important are: intangibility, heterogeneity, simultaneous provision and use of the service. There are five service quality unfavorable gaps, visible in the difference between:

1. provider's predictions and customer preferences,

2. consumer expectations and managers' perceptions of consumer expectations,

3. the delivered and the promised,

4. quality specifications and service delivered,

5. consumer expectations and perception of the quality of service delivered. 
The concept of quality service is conditioned to a great extent by the skills and knowledge of managers responsible for implementation and quality improvement.

There are three basic dimensions of this process:

1. humane dimension (requires inclusion of all employees in the concept of quality),

2. relationship with the users of the service (creating an image based on complete customer satisfaction, checking the quality system from a customer perspective, building a partnership and a quality assurance agreement)

3. technological dimension (geared towards the quality of service, process and quality of the supplier).

\section{Background}

According to $\underline{\text { Adižes (1999) }}$ compatibility between dominant control functions and stages in the pre-occupational life cycle can be observed. In the initial stages, the production function is most pronounced. This means that the management is focused on as large a production volume as the turnover. Quantity is ahead of quality. These features of functioning are also noticed in the catering industry. Mass tourism of the annual-holiday type imposes on the hotel industry the "production" of the service of central quality, that is, the primary orientation towards a stereotyped, depersonalized service, reduced to basic catering components. It seeks to maximize the utilization of capacities for accommodation in conditions of high seasonality of tourist traffic. However, problems arise due to the lack of recognition of changes in demand (Eyton, 1996).

The needs of hotel guests evolve according to changes in lifestyle. The demands for higher comfort, for the rich content of the hotel facility, are more pronounced for faster and more efficient service in terms of receiving, maintaining hygiene, preparing and serving food.

According to Ministry of trade, tourism and telecommunications (2016) motives (expectations) of tourists in Serbia are:

1. an intense holiday,

2. trying something new,

3. living like the locals,

4. the most important segments of a visit to the movable, stationary and non-cultural heritage,

5. growth of group visits to significant celebrations and events,

6. demanding itineraries in short city visits,

7. fitness and sport,

8. wellness breaks,

9. gastronomic tourism,

10. tourism and technology.

Being in the focus of attention in the hotel industry requirements, needs and expectations of the customer as a suitable tool for identifying them and their translation into functional characteristics of services and on-site concrete measures (actions) imposes the quality function deployment - QFD. The application of the QFD method in improving the quality of hotel service and service in general is discussed in the Pun et al. (2000), Pawitra and Tan (2003), Shrivastava and Verma (2014), Baran and Selami (2015), Khanna and Arya (2015). 


\section{Materials and methods}

This method was created in 1966 in Japan, by Yoji Akao (Akao, 1998). It was first used in Mitsubishi Kobe in 1972. After that, Toyota showed the best results in QFD application. Yoji Akao defines QFD as a method of development and design aimed at satisfying users and mapping user requirements into project tasks, with maximum satisfaction of quality requirements through the production phase. According to him, QFD is a way of ensuring product quality at the design stage.

The American Supplier Institute defines QFD as a system for translating customers' requests into the company's relevant requirements at every stage, from research and development, through engineering and manufacturing, to marketing/sales and distribution. Today, the QFD method is successfully used in the manufacture of electronics, clothing, appliances and devices, construction equipment, etc. The famous companies that they use are: Toyota, General Motors, Ford, Motorola, Mazda, Xerox, Kodak, IBM, Helwett-Packard, Procter \& Gamble, AT\&T.

The basic goal of the QFD method is to design a new and improve the existing product, service or process according to the requirements of their users. This goal can be achieved by identifying critical points in the product itself and its development process, which are important for meeting user requirements, in order to define in advance the procedures for their resolution. Sometimes the QFD matrix was used only in design and development, and today it is used in marketing, sales, planning, production, control, etc. The general benefits of

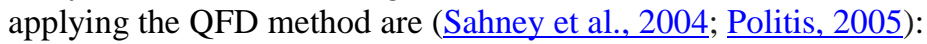

1. reduction of the time and cost of developing, designing and launching products,

2. reduction of the possibility of errors in the phase of defining PRQ,

3. reduction of the cost of subsequent correction,

4. provision of a basis for decision making in terms of improving quality.

QFD method for the service can be described in three-phase action plan, to be implemented within three matrix, so-called House of quality (Gonzalez et al., 2004):

1. service planning (HoQ),

2. process control characteristics matrix (SPEs),

3. action plans matrix.

At the beginning of each of the three "houses of quality" in the left column, there is always the question: "what is required?", And at the exit from the "house of quality" it is always the answer: "HOW to meet the requirements?" Each time the HOW becomes the WHAT in the next matrix.

Phase 1: At the beginning, in the left column, in the "what", enter all customer requirements, ie. requirements that services should meet. Then, in the "How to" define the characteristics of the services that are important to meet customer requirements, entered into the "what". After some processing of these data, the characteristics of services in the fields of "how" from first "house" are transferred in the "what" in other "house".

Phase 2: For all the characteristics of the service, entered in the "WHO" field, are defined in the "HOW" field, critical service process elements - SPEs), which are a significant downgrade of the previous characteristics of the service. This phase is developed as needed, i.e. if it makes sense (if the service can be divided into components), and the problem of narrowing the problem. Critical parts of the service and their characteristics are transferred to the "WHO" field of the third "house" (Gonzalez et al., 2004). 
Phase 3: For all critical parts of the service and their characteristics, entered into the "what", shall be determined in the "HOW" critical processes, ie. operations to achieve critical characteristics of parts of the product. Defining measures can go up to the level of instruction to work. Defining measures are sometimes considered the fourth phase of the QFD process.

Figure 1: A three-phase action plan based QFD flowdown process in the hotel industry

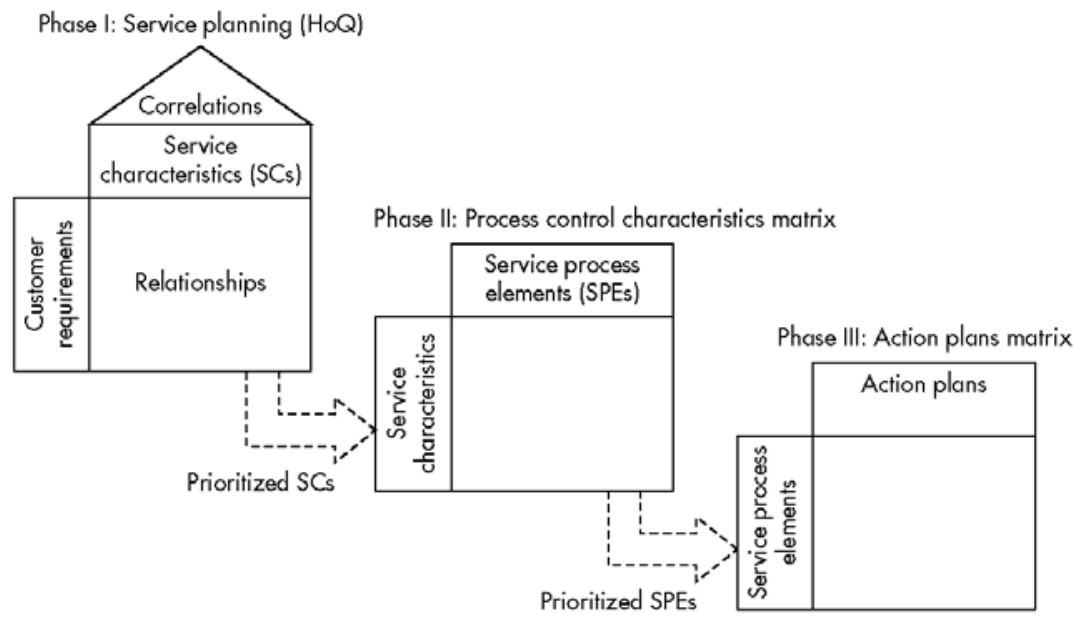

Source: Sullivan, 1986

\section{Results and discussion}

The structured questionnaires were provided to 96 users (guests of five hotels in Central and West Serbia), in order to determine the importance of the particular characteristics of assigning values on a scale of 1 to 5 , where 5 represents the value of a very important requirement, a 1 - requirement with the relatively small importance (Column "importance"). Recorded a total of 42 different customer requirements, of which the first 28 taken for analysis. The variables in Table 1 are defined as follows:

1. rows represent the 28 most significant user requirements,

2. columns are technical characteristics (quality characteristics) of a hotel service defined by experts (hotel management).

In addition to the need to determine the importance of each quality characteristic of hotel services, users are determined as well as the achieved level of service quality on a scale from 1 to 5 (Column "the achieved level"). After that, the connection between the user requirements and technical characteristics (quality characteristics) of hotel service is established. The value 9 indicates a strong relationship, the value 3 - medium (moderate) relationship, the value 1 - a weak relationship, while the value 0 indicates the absence of correlation (Milunović Koprivica \& Filipović, 2018).

The values in the column "competition" represent the achieved level of the observed user requirement with the main competitor. The values in the column "goal" are defined by experts (hotel management and they represent realistically achievable values for each customer requirement, taking into account the need for satisfaction and other customer requirements, the company's ability to improve in that direction, etc. The values in the column "possibility of improvement" were obtained as the quotients of the values in the goal column and the "achieved level" column. Absolute importance is a product of the values 
Milunović Koprivica, S. et al. - QFD method application in the process of hotel service quality improvementHotel and Tourism Management, 2019, Vol. 7, No. 2: 57-66.

from the "possibility of improvement" and "importance” columns. Relative importance was formed based on the values obtained from the previous column (absolute importance). Absolute values for the technical characteristics (quality characteristics) were obtained by multiplying each indicated strength of the relationship by the corresponding relative importance of the user requirement and then the resulting products were summed.

Table 1: The first phase of QFD application for hotel service quality improvement

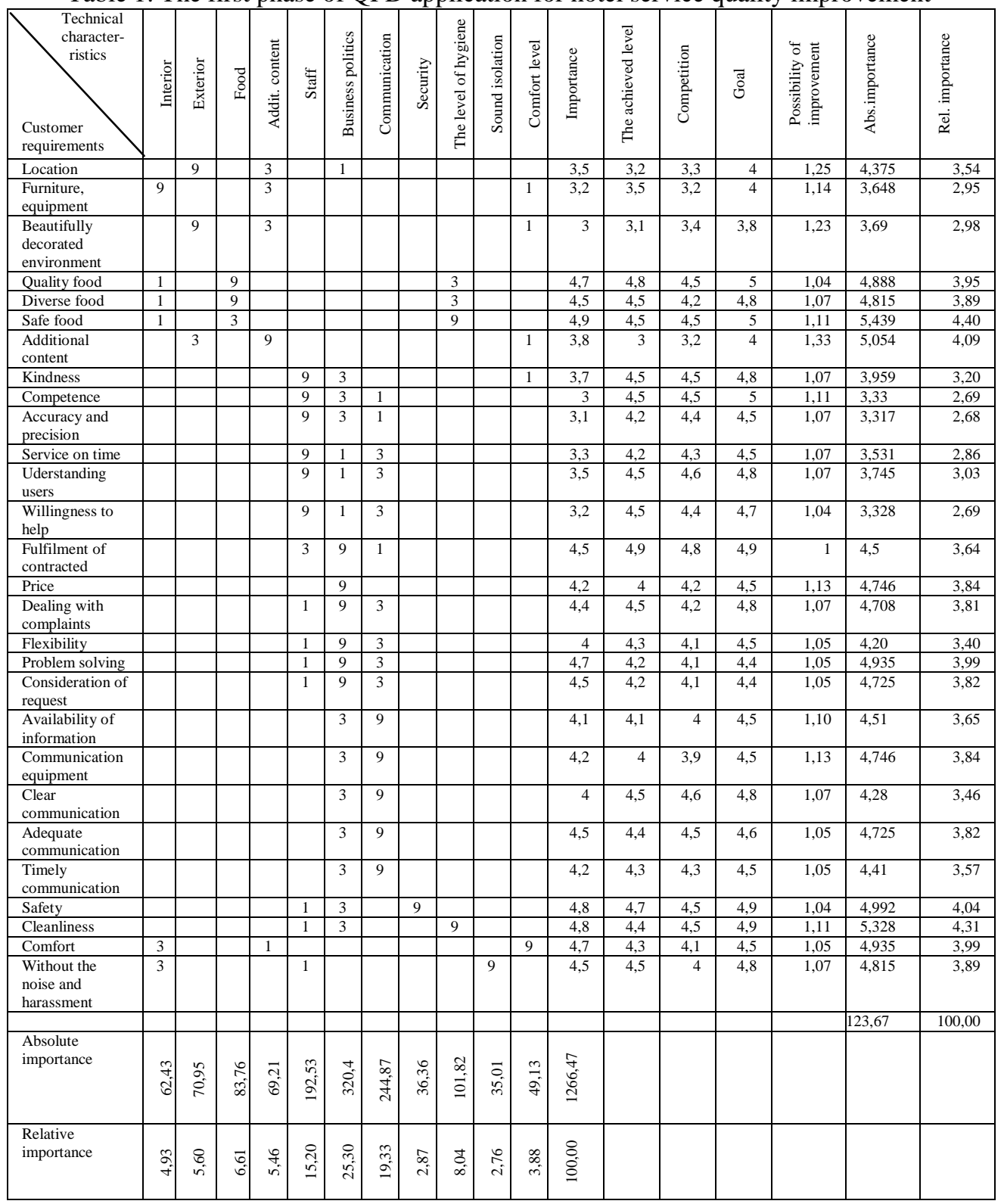

Source: Prepared by the authors

Relative significance was obtained from values from the row for absolute significance. Based on the values for the relative importance of the technical characteristics, it can be seen that the three quality characteristics of the hotel service are by far the most significant (together 
they account for about $50 \%$ of the total value). These are business policy, communication and staff (employees). Since these three quality features are much more important than the others, they need to be given the utmost attention in developing (improving) the hotel service. Everything that is done and presented in Table 1 represents the first phase of the QFD method.

In the second phase for prioritized SCs defined service process elements (SPEs) - Table 2.

Table 2: Process control characteristics matrix

\begin{tabular}{|l|l|}
\hline \multirow{4}{*}{ Business politics } & Corresponds to the objectives and business plans \\
\cline { 2 - 3 } & Contains a commitment to meet customer requirements \\
\cline { 2 - 3 } & Follow the competition \\
\cline { 2 - 3 } Communication & Follow the latest trends in the hotel industry \\
\hline & Use of modern IT \\
\cline { 2 - 2 } & Web site with updated information \\
\cline { 2 - 2 } & Informing the user in a way that best suits them (of their choice) \\
\cline { 2 - 2 } & The information available 24 hours a day \\
\hline \multirow{4}{*}{ Staff } & Staff uniform \\
\cline { 2 - 2 } & Staff knowledge level \\
\cline { 2 - 2 } & Staff behavior \\
\cline { 2 - 2 } & Motivation \\
\cline { 2 - 2 } & Teamwork \\
\hline
\end{tabular}

Source: Prepared by the authors

In the third phase of the QFD method, a list of actions (actions) for each SPEs was created and thus an Action plan matrix (Table 3) was constructed.

Table 3: Action plan matrix

\begin{tabular}{|l|l|}
\hline SPEs & Action plan \\
\hline \multirow{4}{*}{$\begin{array}{l}\text { Business politics corresponds } \\
\text { to the objectives and business } \\
\text { plans }\end{array}$} & $\begin{array}{l}\text { Reconsideration business policy within a reasonable } \\
\text { timeframe (once a year) }\end{array}$ \\
\cline { 2 - 2 } & Reconsideration of business objectives and plans \\
\cline { 2 - 2 } & $\begin{array}{l}\text { Alignment of business policy with the goals and plans } \\
\text { of the business }\end{array}$ \\
\hline \multirow{3}{*}{$\begin{array}{l}\text { Business politics contains a } \\
\text { commitment to meet customer } \\
\text { requirements }\end{array}$} & Determining user requirements \\
\cline { 2 - 2 } & Determining the degree of user satisfaction \\
\cline { 2 - 2 } $\begin{array}{l}\text { Business politics follow the } \\
\text { competition }\end{array}$ & $\begin{array}{l}\text { A special place for the user in the business policy of the } \\
\text { hotel }\end{array}$ \\
\cline { 2 - 2 } & Determining competitors list \\
\cline { 2 - 2 } $\begin{array}{l}\text { Business politics follow the } \\
\text { latest trends in the hotel } \\
\text { industry }\end{array}$ & $\begin{array}{l}\text { Benitoring the activities of competitors } \\
\text { field of hotel management }\end{array}$ \\
\cline { 2 - 2 } & Continuous improvement of employees of all levels \\
\cline { 2 - 2 } & Procurement of modern equipment \\
\hline
\end{tabular}


Milunović Koprivica, S. et al. - QFD method application in the process of hotel service quality improvementHotel and Tourism Management, 2019, Vol. 7, No. 2: 57-66.

\begin{tabular}{|c|c|}
\hline \multirow{3}{*}{$\begin{array}{l}\text { Use of modern IT for } \\
\text { communication }\end{array}$} & Convenient equipment \\
\hline & Staff trained in the application of modern IT technology \\
\hline & Protection of user data \\
\hline \multirow{3}{*}{$\begin{array}{l}\text { Web site with updated } \\
\text { information }\end{array}$} & $\begin{array}{l}\text { The ability to inform the user about all aspects of the } \\
\text { service through the website }\end{array}$ \\
\hline & $\begin{array}{l}\text { Determining the person responsible for maintenance } \\
\text { website }\end{array}$ \\
\hline & Updating the website \\
\hline \multirow{3}{*}{$\begin{array}{l}\text { Informing the user in a way } \\
\text { that best suits them (of their } \\
\text { choice) }\end{array}$} & User survey \\
\hline & Present possible ways of communication to the user \\
\hline & $\begin{array}{l}\text { Use a communication and notification mode tailored to } \\
\text { each individual user }\end{array}$ \\
\hline \multirow{3}{*}{$\begin{array}{l}\text { The information available } 24 \\
\text { hours a day }\end{array}$} & Reception open 24 hours \\
\hline & High speed internet available in rooms \\
\hline & $\begin{array}{l}\text { Availability of phones, fax machines, computers to } \\
\text { hotel guests }\end{array}$ \\
\hline \multirow{3}{*}{ Staff uniform } & Uniform which represents the firm \\
\hline & According to gender \\
\hline & According to the rank Form/Badge \\
\hline \multirow{3}{*}{ Staff knowledge level } & Selection of candidates when hiring \\
\hline & $\begin{array}{l}\text { Application of the } \\
\text { rotation system - weekly and monthly applications }\end{array}$ \\
\hline & $\begin{array}{l}\text { Examination system - Staff assessment examination } 4 \\
\text { times a year }\end{array}$ \\
\hline \multirow{3}{*}{ Staff behavior } & Kindness and thoughtfulness \\
\hline & Compliments and praise \\
\hline & Taking care of colleagues \\
\hline \multirow{3}{*}{ Motivation } & $\begin{array}{l}\text { At the end of each month, you should make it clear that } \\
\text { you see who is good at their job and who is trying and } \\
\text { who is not }\end{array}$ \\
\hline & $\begin{array}{l}\text { A survey among employees with questions about } \\
\text { favorite foods, tourist destinations, etc. }\end{array}$ \\
\hline & Best Employee Rewards \\
\hline \multirow{3}{*}{ Teamwork } & Organization of teambuilding gatherings \\
\hline & Promoting the quality of teamwork \\
\hline & Award to the best teams \\
\hline
\end{tabular}

Source: Prepared by the authors

\section{Conclusion}

The quality management system is increasingly becoming an objective need in the hotel industry. Acceptance of this concept is in fact the commitment to the quality of hotel services, its achievement, maintenance, measurement, control and improvement. This means defining the flow of supply in the essence of heterogeneous services in a way that reduces oscillations in quality to a minimum. This provides a greater degree of harmonization between expectations and the actual experience of consumers, and with greater certainty 64 
leads to satisfied customers. The main goal of the hotel business is a satisfied guest. Being satisfied with the highly individualized service activity such as hotel management, it can be done by professional, motivated and satisfied people. It is a difficult challenge for hotel management, but also the only way to profit, reaching and maintaining the top form, the word of a successful business hotel company.

The aim of this paper is identification of the most important quality characteristics (technical characteristics) of the hotel service and direction of the activities of the hotel management to those characteristics that can be related to the highest number of stated customer requirements. In order to achieve this aim, the requirements of hotel service users in 5 hotels of Central and Western Serbia were identified. The survey included a total of 96 hotel service users. A total of 42 different requirements for hotel service were identified and 28 most important requirements were considered. Using the QFD three-phase method in hotel service, SPEs with the highest relative importance were identified. This will serve as the basis for hotel management to make appropriate decisions when it comes to improving the quality of hotel services. The SPEs with the greatest importance are business politics of the hotel, communication and staff. For these three SPEs, concrete actions for their achievement in the third phase of QFD process are defined. It follows from all of the foregoing that in order to improve the quality of hotel services in terms of satisfying the stated user requirements, the biggest part in the hands, i.e. the decisions of the management which define business politics, establish ways and provide resources for communication with users and make decisions on all matters related to the selection and operation of staff.

\section{Study limitations and future research}

The main disadvantages of applying QFD methods identified by an ambiguity in determining the user's voice and the necessity of working with a large amount of subjective data. Therefore, the subject of the authors' future research will be the application of the tools that treat imprecision, uncertainty and subjectivity. They appear when a user identifies, evaluates and assigns importance of the achieved level of certain characteristics of quality hotel services. They appear, too, when the hotel management team determines the target value and the ability to improve the characteristics, which directly affects the relative importance of the user requests or the functional characteristics of hotel services. The fortified relative importance of the member's request/functional characteristics as determined by the activities and resources will be given greater attention in the process for quality improvement of hotel services.

\section{References}

1. Adizes, I. (1999). Aspiration to top form. Novi Sad: Adizes management consulting.

2. Akao, Y. (1998). QFD concepts. Proceedings of the Advanced QFD Course, QFD Institute, Novi, MI.

3. Baran Z., \& Selami Yıldız, M. (2015). Quality function deployment and application on a fast food restaurant. International Journal of Business and Social Science, 6(9), 122131.

4. Boucherau, V., \& Rowlands, H. (2000). Methods and techniques to help Quality Function Deployment (QFD). Benchmarking: An International Journal, 7(1), 8-19. https://doi.org/10.1108/14635770010314891

5. Cauchick Miguel, P. A. (2005). Evidence of QFD best practices for product development: a multiple case study. International Journal of Quality \& Reliability Management, 22(1), 72-82. https://doi.org/10.1108/02656710510573002 
6. Gonzalez, M. E., Quesada, G., Mueller, R., \& Mora-Monge, C. A. (2004). QFD strategy house: an innovative tool for linking marketing and manufacturing strategies. Marketing Intelligence \& Planning, 22(3), 335-348. https://doi.org/10.1108/02634500410536911

7. Gonzalez, M., Quesada, G., Picado, F., \& Eckelman, C. (2004). Customer satisfaction using QFD: An E-Banking case. Managing Service Quality, 14(4), 317-330. https://doi.org/10.1108/09604520410546851

8. Eyton, R. (1996). Making innovation fly. Ivey Business Quarterly, 61(1), 59.

9. Khanna, S., \& Arya, V. (2015). Study of quality function deployment (QFD) in service industry. International Journal of Advanced Engineering and Global Technology, 3(10), 1233-1244.

10. Milunović Koprivica, S., \& Filipović, J. (2018). Application of traditional and fuzzy quality function deployment in the product development process. Engineering Management Journal, 30(2), 98-107. https://doi.org/10.1080/10429247.2018.1438027

11. Ministry of trade, tourism and telecommunications. (2016). Strategy for tourism development of the Republic of Serbia for the period 2016-2025. Retrieved November 10, 2016 from http://demo.paragraf.rs/demo/combined/Old/t/t2016_12/t12_0189.htm

12. Pawitra, T. A., \& Tan K. C. (2003). Tourist satisfaction in Singapore - A perspective from Indonesian tourists. Managing Service Quality, 13(5), 399-411. https://doi.org/10.1108/09604520310495868

13. Politis, J. D. (2005). QFD, organisational creativity and productivity. International Journal of Quality \& Reliability Management, 22(1), 59-71. https://doi.org/10.1108/02656710510572995

14. Pun, K. F., Chin, K. S., \& Lau, H. (2000). A QFD/Hoshin approach for service quality deployment: A case study. Managing Service Quality, 10(3), 156-170. https://doi.org/10.1108/09604520010336687

15. Redžić, D. (2018). Significance of quality in the tourism industry: Research study on the perception of stakeholders in tourism. Menadžment u hotelijerstvu i turizmu - Hotel and Tourism Management, 6(2), 11-20, https://doi.org/10.5937/menhottur1802011R

16. Sahney, S., Banwet, D. K., \& Karunes, S. (2004). A SERVQUAL and QFD approach to total quality education: A student perspective. International Journal of productivity and performance management, 53(2), 143-166. https://doi.org/10.1108/17410400410515043

17. Shrivastava, P., \& Verma, S. D. (2014). Application of quality function deployment to improve customer satisfaction in hotel industry. International Journal of Scientific \& Engineering Research, 5(6), 957-962.

18. Sullivan, L. P. (1986). Quality function deployment. Quality Progress, June, 39-50.

Received: 9 June 2019; Sent for revision: 11 September 2019; Accepted: 21 October 2019 